\title{
THE CANONICAL WNT PATHWAY IN GASTRIC CARCINOMA
}

\author{
Via canônica do Wnt no carcinoma gástrico
}

\author{
Levindo Alves de OLIVEIRA ${ }^{1}$, Celina Tizuko Fujiyama OSHIMA², Pedro Augusto SOFFNER ${ }^{3}$, \\ Marcelo de Souza SILVA², Rodrigo Rego LINS ${ }^{1}$, Andréa Cristina de Moraes MALINVERNI², Jaques WAISBERG ${ }^{1,3}$
}

Como citar este artigo: Oliveira LA, Oshima CTF, Soffner PA, Silva MS, Lins RR, Malinverni ACM, Waisberg J. Via canônica do wnt no carcinoma gástrico. ABCD Arq Bras Cir Dig. 2019;32(1):e1414. DOI: /10.1590/0102-672020180001e1414

From the 'Programa Interdisciplinar de Ciências Cirúrgicas e ${ }^{2}$ Laboratório de Patologia Molecular e Experimental, Departamento de Patologia, Universidade Federal de São Paulo, UNIFESP/EPM, São Paulo, SP; ${ }^{3}$ Departamento de Cirurgia, Faculdade de Medicina do ABC, Santo André, SP ('Interdisciplinar Program in Surgical Sciences and 'Laboratory of Molecular and Experimental Pathology, Department of Pathology, Federal University of São Paulo, UNIFESP/EPM, São Paulo, SP; ${ }^{3}$ Department of Surgery, ABC Medical School, Santo André, SP), Brazil

HEADINGS - Gastric carcinoma. Wnt signaling pathways. Immunohistochemistry. Signal transduction.
ABSTRACT - Background: It is believed that the Wnt pathway is one of the most important signaling involved in gastric carcinogenesis. Aim: To analyze the protein expression of canonical and non-canonical Wnt pathways in gastric carcinoma. Method: The immunohistochemistry was performed in 72 specimens of gastric carcinomas for evaluating the expression of Wnt5a, FZD5, GSK3 $\beta$, axin, CK1, ubiquitin, cyclin D1 and c-myc. Results: There were significant differences for cytoplasm and nucleus ubiquitin for moderately and well differentiated tumors $(p=0.03)$ and for those of the intestinal type of the Lauren classification $(p=0.03)$. The absence of $c-m y c$ was related to Lauren's intestinal tumors $(p=0.03)$. Expression of CK1 in the cytoplasm was related to compromised margin $(p=0.03)$. Expression of cyclin D1 protein was more intense in male patients $(p=0.03)$ There was no relation of the positive or negative expression of the Wnt-5a, FZD5, GSK3 and Axin with any clinicopathological variables. Conclusion: The canonical WNT pathway is involved in gastric carcinoma.

\section{Correspondence:}

Celina Tizuko Fujiyama Oshima

Email: celina.oshima@gmail.com

Financial source: none

Conflict of interest: none

Received for publication: 07/08/2018 Accepted for publication: 25/09/2018

DESCRITORES - Neoplasias Gástricas. Vias de Sinalização Wnt. Imunoistoquímica. Transdução de Sinal.
RESUMO - Racional: Acredita-se que a via Wnt é uma das mais importantes da sinalização envolvidas na carcinogênese gástrica. Objetivos: Analisar a expressão das proteínas das vias Wnt canônicas e não-canônicas no carcinoma gástrico e relacionar sua expressão com as variáveisclinicopatológicas. Método: Foram coletadas 72 amostras de carcinoma gástrico, e áreas representativas do tumor foram selecionadas para o Tissue Microarray. Imunoistoquímica foi realizada para avaliar a expressão de Wnt-5a, FZD5, GSK3ß, axina, CK1, ubiquitina, ciclina D1 e c-myc. Resultados: Houve diferenças significativas para a expressão de ubiquitina no citoplasma e núcleo para tumores moderadamente e bem diferenciados $(p=0,03)$ e para aqueles do tipo intestinal da classificação de Lauren $(p=0,03)$. A expressão negativa da proteína c-myc no citoplasma foi relacionada aos tumores intestinais de Lauren $(p=0,028)$. A expressão positiva de CK1 no citoplasma das células neoplásicas foi relacionada a tumores com margens cirúrgicas livre de envolvimento neoplásico $(p=0,03)$. A expressão positiva da proteína ciclina D1 foi maior nos tumores dos homens $(p=0,03)$. Não houve relação da expressão positiva ou negativa das proteínas Wnt-5a e FZD5 no citoplasma ou núcleo com quaisquer variáveis clinicopatológicas. O mesmo foi observado para GSK3 $\beta$ e Axin. Conclusões: A relação da expressão das proteínas da via canônica com as variáveis epidemiológicas e tumorais sugere sua participação na carcinogênese gástrica. Por outro lado, a ausência da relação das expressões das proteínas da via não-canônica sugere sua não participação na carcinogênese gástrica.

\section{INTRODUCTION}

G astric carcinoma has high global incidence and low average survival in both developed and developing countries. Despite several advances in conventional therapy, recurrence rates remain high and survival rates low $1,7,11,12,16,17,26,30,35$.

Changes such as mutations, deletions, inactivation by viruses and bacteria, and hypermethylation were involved in the onset of gastric cancer ${ }^{7,16,28,32}$. Wnt genes encode signaling proteins and are found in the genomes of all animals. Signaling is initiated when ligands of Wnt pathway are attached in a complex consisting of a receptor of frizzled family and a member of the family of low density lipid receptors ${ }^{24}$. The key molecule of the cascade is the cytoplasmic betacatenin protein whose stability is regulated by the so-called "destruction complex"7,16,32.

Wnt proteins play an important role in embryogenesis and maturation of tissues. These proteins act as ligands to components of frizzled family that are transmembrane cellular receptors. Once attached to these receptors, Wnt proteins can activate two distinct pathways of cell signaling: canonical and non-canonical pathways. Several proteins are involved in both of them ${ }^{14,17,32}$.

Often, the Wnt signaling pathway is involved in gastric carcinogenesis and several proteins of this pathway may be mutated or expressed atypically in gastric tumor tissue. 
However, the involvement and mechanisms of Wnt pathway in the onset of gastric cancer are not fully understood as in colorectal cancer ${ }^{8,32}$.

A previous study from our research group suggested that the WNT/ $\beta$-catenin pathway may be involved in gastric cancer. Lins et al. (2016) ${ }^{24}$ analyzed the expression of E-cadherin, beta-catenin, APC, TCF-4 and survivin in gastric cancer tissues by immunohistochemistry and verified relationship between the expression of the proteins and age of the patients and the anatomopathological aspects of gastric carcinoma as location, Lauren classification and degree of tumor penetration into the gastric wall.

In order to identify another Wnt pathway proteins in these same samples we propose the study of two non-canonical pathway proteins (Wnt-5a, FZD5) and six canonical pathways proteins (GSK3B, axin, CK1, ubiquitin, cyclin D1 and MYC) and relate their expression with epidemiological and anatomopathological characteristics of the tumor.

\section{METHODS}

The Ethic Review Committee at Federal University of São Paulo (UNIFESP), São Paulo, SP, Brazil, approved the study protocol (Registration no 1.128.919/2015).

A total of 72 specimens of primary gastric carcinomas (GC) were collected from patients who underwent radical surgical resection at the Department of General Surgery of ABC Medical School, SP, Brazil, from January 2007 to December 2010. The patients' medical records were reviewed to determine their age, gender, anatomical site, tumor size, histological grade and the presence or absence of lymphatic, vascular or neural invasion. The inclusion criteria were patients aged over 18 years, of both gender, whom had undergone curative or palliative gastrectomy without neoadjuvant radio or chemotherapy, with histological examination confirming gastric adenocarcinoma.

\section{TMA construction}

TMA blocks, also called receptor block, were constructed at the Laboratory of Molecular and Experimental Pathology, Department of Pathology, Federal University of São Paulo using the paraffin blocks containing the tissue of gastric cancer from the Department of Pathology, ABC Medical School. Representative areas selected by a pathologist of the 72 gastric carcinomas were selected from $\mathrm{H} \& \mathrm{E}$ stained sections. The selected area was marked in the respective paraffin block. A cylindrical core was created in the receptor block using Beecher ${ }^{\mathrm{TM}}$ equipment (Beecher Instruments, Silver Spring, MD, USA). A 1 mm cylinder of tissue was extracted from the selected area of the donating block and was transferred to the core in the receptor block. New core positions were created in the receptor block, separated by fractions of $1 \mathrm{~mm}$ such that a collection of tissue samples was created following the matrix arrangement.

\section{Immunohistochemistry}

It was performed at Experimental Molecular Pathology Laboratory I Department of Pathology for evaluating the expression of Wnt-5a, FZD5, GSK3B, axin, CK1, ubiquitin, cyclin D1 and c-myc proteins according Gomes et al. (2011) ${ }^{13}$; da Silva et al. (2013) ${ }^{10}$.

Sections of $3 \mu \mathrm{m}$ obtained from the TMA blocks were mounted on 3-aminopropylotrimetoxy-silane coated slides (Sigma), dewaxed in xylene, taken through ethanol to water to rehydrate. For antigen retrieval slides were placed in $0,01 \mathrm{M}$ citrate-buffer $\mathrm{pH} 6.0$ and heated in a steamer for $30 \mathrm{~min}$. Endogenous peroxidase activity was blocked by incubating the sections in a solution of $3 \%$ hydrogen peroxide for $20 \mathrm{~min}$ at room temperature. After these procedures, the sections were incubated with Wnt-5a (AF645) (1:100) and FZD5 (AF1617) purchased from R \& D Systems, Inc, Minneapolis, MN, USA),
GSK3ß (sc-9166) (1:200); axin (sc-14029) (1:100); CK1 (sc-74582) (1:100); cyclin D1 (sc-8396) (1:100); c-myc (sc-40) (1:1000) and ubiquitin (sc-8017) (1: 150) purchased from Santa Cruz Biotechnology, Dallas, TX, USA) at $4^{\circ} \mathrm{C}$ overnight. The sections were washed with PBS and allowed to react with LSAB + SystemHRP (Biotinylated Link Universal) (Streptavidin-HRP) (Dako North America Inc.) for 30 min. Finally, staining was carried out using Liquid DAB+substrate chromogen system (Dako North America, Inc.) lightly counterstained with Harris hematoxylin and cover slipped with Entellan (Sigma). Negative and positive controls were made to run simultaneously. Positive control was represented by colon adenocarcinoma tissue. Negative controls were made by eliminating the primary antibody.

\section{Interpretation of reaction results}

The staining patterns (membrane, cytoplasm and nucleus) were analyzed according to the criteria of distribution and intensity of staining. This analysis was semi-quantitative. A numerical scoring system with two categories was used to assess protein expression. The intensity of the staining was classified as negative ( 0 point), weak ( 1 point), moderate ( 2 points) and strong ( 3 points). The extent of the positive immunostaining area was classified as less than $10 \%$ (0 point), $11-25 \%$ (1 point), $26-50 \%$ ( 2 points) and above $50 \%$ (3 points). The intensity of the reaction was multiplied by the extension of the staining and the results were categorized into a score of 0 to 9 . The reactions with score $\geq 4$ were considered as positive and those with a score $<4$ were considered negative ${ }^{8,32}$. To evaluate the expression of proteins was used the Eclipse 80i-Nikon microscope. Representative areas of gastric adenocarcinoma tissue were captured using a Sony camera under 400X.

\section{Statistical analysis}

Descriptive analysis of the qualitative variables was done by the distribution of absolute frequency (n) and relative frequency (\%). The comparison between the expression of each protein was performed by the Fisher's exact test and the value of $p<0.05$ was considered significant.

\section{RESULTS}

Clinicopathological data from the patients with gastric cancer are summarized in Table 1. Forty-five cases were men and 25 cases were women with a mean age of 65 years. Fortysix tumors were from the proximal region while 39 tumors were larger than $5 \mathrm{~cm}$. No compromised surgical margin was observed in 63 cases. Venous invasion was identified in 23 patients and lymphatic invasion in 39 . Perineural invasion was present in 43 patients. In 38 the tumors were moderately or well differentiated and Lauren classification included 49 intestinal adenocarcinomas and 21 diffuse adenocarcinomas. TNM staging showed that more than $50 \%$ of the patients were in the advanced stage of the disease.

Figure 1 shows photomicrography of immunohistochemistry results of Wnt-5a, FZD5, GSK3 $\beta$, Axin, Ubiquitin, Cyclin D1, c-myc and CK1 proteins in gastric adenocarcinoma tissues.

Table 2 shows the presence or absence of Wnt-5a, FZD5, GSK3 $\beta$, axin, CK1, ubiquitin, cyclin D1 and c-myc proteins in gastric adenocarcinoma tissues. No protein studied showed membrane marking.

There were significant differences for ubiquitin expression in the cytoplasm and nucleus for moderately and well differentiated tumors $(p=0.03)$ and for those of the intestinal type of the Lauren classification $(p=0.03)$. The negative expression of $c-m y c$ protein in the cytoplasm was related to Lauren's intestinal tumors $(p=0.028$, Table 3$) . G S K 3 \beta$, axin proteins expressions and nuclear expression of c-myc were not related to any clinicopathological variables. However, we note that axin protein expression in nucleus and cytoplasm was more intense in moderately well 
differentiated tumors and those of Lauren's intestinal type but without statistical significance. Positive expression of CK1 in the cytoplasm of neoplastic cells was related to tumors showing a surgical margin free of neoplastic involvement $(p=0.03)$. The positive expression of cyclin D1 protein was more intense in the tumors of male patients $(p=0.03)$ but was not related to no other clinicopathological variables. There was no relation of the positive or negative expression of the Wnt-5a and FZD5 proteins in the cytoplasm or nucleus with any clinicopathological variables.

TABLE 1 - Clinicopathological variables of samples

\begin{tabular}{|c|c|c|}
\hline Variables & & $\mathrm{n}(\%)$ \\
\hline \multirow{2}{*}{ Age } & $>50$ & $64(90.3)$ \\
\hline & $\leq 50$ & $7(9.7)$ \\
\hline \multirow{2}{*}{ Gender } & Male & $45(64.3)$ \\
\hline & Female & 25 (35.7) \\
\hline \multirow{2}{*}{ Tumor location } & Distal & $26(36.1)$ \\
\hline & Proximal & 46 (63.9) \\
\hline \multirow{2}{*}{ Tumor size } & $>5 \mathrm{~cm}$ & 39 (54.9) \\
\hline & $\leq 5 \mathrm{~cm}$ & $32(45.1)$ \\
\hline \multirow{2}{*}{ Margin compromised } & absent & $63(90)$ \\
\hline & present & $7(10)$ \\
\hline \multirow{2}{*}{ Venous invasion } & absent & $46(66.7)$ \\
\hline & present & $23(33.3)$ \\
\hline \multirow{2}{*}{ Lymphatic invasion } & absent & $30(43.5)$ \\
\hline & present & $39(56.5)$ \\
\hline \multirow{2}{*}{ Perineural invasion } & absent & $26(37.7)$ \\
\hline & present & $43(62.3)$ \\
\hline \multirow{2}{*}{ Differentiation grade } & well/moderate & $38(55.9)$ \\
\hline & little/undifferentiated & $30(44.1)$ \\
\hline \multirow{5}{*}{ T stage } & 0 & $1(1.4)$ \\
\hline & 1 & $2(4.2)$ \\
\hline & 2 & $17(23.6)$ \\
\hline & 3 & $41(56.9)$ \\
\hline & 4 & 10 (13.9) \\
\hline \multirow{2}{*}{$\mathrm{N}$ stage } & 0 & $24(34.7)$ \\
\hline & $1 / 2 / 3$ & $46(65.3)$ \\
\hline \multirow{2}{*}{ Lauren classification } & Intestinal & $49(69.4)$ \\
\hline & diffuse & $21(30.6)$ \\
\hline \multirow[t]{2}{*}{ N } & 0 & $24(34,7)$ \\
\hline & $1 / 2 / 3$ & $46(65,3)$ \\
\hline \multirow[t]{2}{*}{ Lauren classification } & Intestinal & $49(69,4)$ \\
\hline & diffuse & $21(30,6)$ \\
\hline
\end{tabular}

TABLE 2 - Presence or absence of Wnt-5a, FZD5, GSK3 $\beta$, axin, CK1, ubiquitin, cyclin D1 and c-myc proteins in gastric adenocarcinoma tissues

\begin{tabular}{|c|c|c|c|c|}
\hline Protein & Location & $\mathrm{n}$ & Positive (\%) & Negative (\%) \\
\hline \multirow{2}{*}{ Wnt-5a } & cytoplasm & 71 & 24 (33.8) & $47(66.2)$ \\
\hline & nucleus & 72 & 59 (81.9) & 13 (18.1) \\
\hline FZD5 & cytoplasm & 72 & $2(2.8)$ & 70 (97.2) \\
\hline \multirow{2}{*}{ GSK3 $\beta$} & cytoplasm & 65 & 64 (98.5) & $1(1.5)$ \\
\hline & nucleus & 65 & 65 (100) & - \\
\hline \multirow{2}{*}{ Axin } & cytoplasm & 67 & $63(94)$ & $4(6)$ \\
\hline & nucleus & 67 & $67(100)$ & - \\
\hline CK1 & cytoplasm & 67 & $58(86.6)$ & $9(13.4)$ \\
\hline \multirow{2}{*}{ Ubiquitin } & cytoplasm & 67 & $62(92.5)$ & $5(7.5)$ \\
\hline & nucleus & 67 & $62(92.5)$ & $5(7.5)$ \\
\hline Cyclin D1 & nucleus & 64 & 35 (64.7) & $29(45.3)$ \\
\hline \multirow{2}{*}{$c-m y c$} & cytoplasm & 66 & $16(24.2)$ & $50(75.8)$ \\
\hline & nucleus & 70 & $30(42.9)$ & $40(57.1)$ \\
\hline
\end{tabular}

FIGURE 1 - Photomicrography of immunohistochemistry

\section{DISCUSSION}

TheWntpathway is frequently involved in gastric carcinogenesis and the canonical pathway is considered the most important

and c-myc (cytoplasm) proteins in gastric adenocarcinoma tissues.

\begin{tabular}{|c|c|c|c|c|}
\hline & & $\begin{array}{c}\text { Negative } \\
\text { n (\%) }\end{array}$ & $\begin{array}{l}\text { Positive } \\
\text { n (\%) }\end{array}$ & $\mathrm{p}$ \\
\hline \multicolumn{5}{|l|}{$\begin{array}{l}\text { Ubiquitin } \\
\text { (cytoplasm) }\end{array}$} \\
\hline \multirow[b]{2}{*}{ Differentiation grade } & well/moderate & - & $35(100)$ & \multirow[b]{2}{*}{$0,03^{*}$} \\
\hline & $\begin{array}{c}\text { little/ } \\
\text { undifferentiated }\end{array}$ & $4(13.8)$ & $25(86.02)$ & \\
\hline \multirow{2}{*}{ Lauren classification } & Intestinal & $1(2.2)$ & $45(97.8)$ & \multirow{2}{*}{$0.03^{*}$} \\
\hline & Diffuse & $4(19)$ & $14(81)$ & \\
\hline \multicolumn{5}{|l|}{ Ubiquitin (nucleus) } \\
\hline \multirow[b]{2}{*}{ Differentiation grade } & well/moderate & - & $30(100)$ & $0.04^{*}$ \\
\hline & $\begin{array}{c}\text { little/ } \\
\text { undifferentiated }\end{array}$ & $4(13.8)$ & $25(86.02)$ & \\
\hline \multirow{2}{*}{ Lauren classification } & Intestinal & $1(2.2)$ & $45(97.8)$ & $0.03^{*}$ \\
\hline & Diffuse & $4(19)$ & $14(81)$ & \\
\hline \multicolumn{5}{|l|}{ CK1 (cytoplasm) } \\
\hline \multirow{2}{*}{ Margin committed } & absent & $6(10,2)$ & $53(89,8)$ & $0,03^{*}$ \\
\hline & present & $3(50,0)$ & $3(50,0)$ & \\
\hline \multicolumn{5}{|l|}{ Ciclina D1 (nuclear) } \\
\hline \multirow{2}{*}{ Gender } & masculino & $15(35,7)$ & $27(64,3)$ & $0,03^{*}$ \\
\hline & feminino & $14(63,6)$ & $8(36,4)$ & \\
\hline \multicolumn{5}{|l|}{ c-myc (cytoplasm) } \\
\hline \multirow{2}{*}{ Lauren classification } & Intestinal & $31(67.4)$ & $15(32.6)$ & $0.028^{*}$ \\
\hline & Diffuse & $19(95)$ & $1(5)$ & \\
\hline
\end{tabular}

$n=$ number of samples; Fisher exact test ${ }^{*}=$ significant

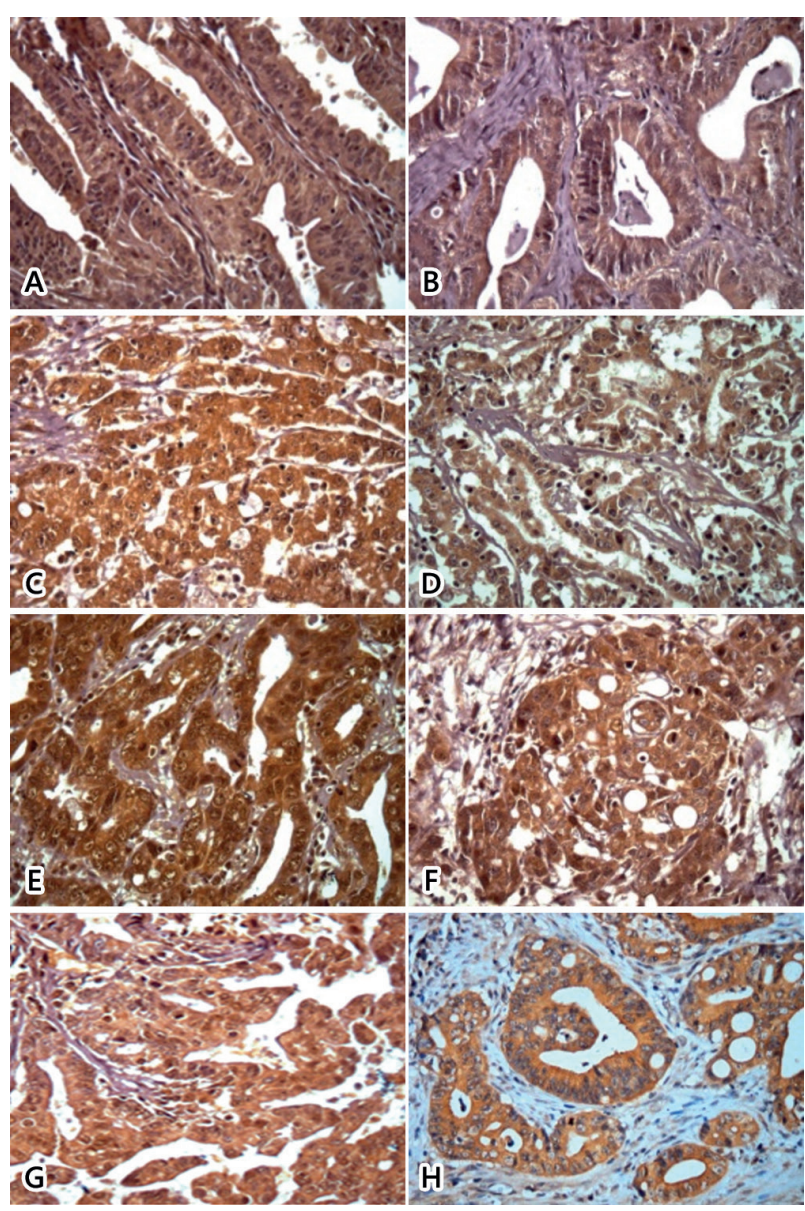

n=sample number
results of proteins in gastric adenocarcinoma tissues: $A=$ Wnt-5a; $B=F Z D 5 ; C=G S K 3 \beta ; D=$ axin; $\mathrm{E}=$ ubiquitin; $\mathrm{F}=$ ciclin $\mathrm{D} 1 ; \mathrm{G}=\mathrm{c}-\mathrm{myc} ; \mathrm{H}=\mathrm{CK} 1$


in its carcinogenesis. However, the non-canonical pathway has also been related to the genesis of gastric neoplasm ${ }^{5,8,18,32}$.

The Wnt-5a protein is considered to inhibit the canonical signaling pathway and is considered a tumor suppressor. In the present study, the positive expression of Wnt-5a and FZD5 was not related to the variables studied. The immunohistochemical study of Kurayoshi et al.(2006) ${ }^{22}$ showed abnormal expression of Wnt-5a in 71 of 237 cases of gastric cancer. The positivity of Wnt-5a was correlated with advanced stages of the neoplasia and with the worse prognosis of the patients. Ara et al. (2016) evaluated the relationship of Wnt-5a to laminin g2, a protein related to cell adhesion and neoplastic invasion. The results suggested that Wnt-5a protein is involved in the progression of gastric cancer, a finding similar to that of other authors ${ }^{15,29,33}$ Zhang et al. (2015) ${ }^{34}$ showed that positive expression of Wnt-5a is related to the better prognosis of gastric carcinoma. On the other hand, FZD5 receptors receive canonical and non-canonical pathways signal, being important in the Wnt pathway. However, the FZD5 protein was more related to the non-canonical Wnt pathway ${ }^{31}$.

GSK3 is a multifunctional protein involved in mammalian cell regulatory pathways, including Wnt pathway, and it is part of the $\beta$-catenin destruction complex. In the present study, we identified a strong expression of the GSK3B protein in the nucleus and in the cytoplasm, but there was no relation to the epidemiological variables of the patients and anatomopathological of the tumor, which was also observed by other authors ${ }^{31,34}$. Cho et al. (2010) ${ }^{9}$ analyzed the expression of GSK3B in 281 cases of gastric carcinoma. Positive expression of this protein was related to early tumors, without lymph node metastases and without angiolymphatic invasion.

The axin protein is part of the $\beta$-catenin destruction complex and acts as a tumor suppressor. Mutations in genes that synthesize axin are related to the genesis of hepatocellular carcinoma, endometrial adenocarcinoma and medulloblastoma ${ }^{20,25}$. In this study, axin protein expression was more intense in the nucleus than in the cytoplasm and was identified in $100 \%$ of the nuclei of gastric carcinoma cells. Cytoplasmic expression was also intense and predominated in moderately or well differentiated tumors and in intestinal type of Lauren's classification ${ }^{23}$. Kim et al. (2014) ${ }^{20}$ showed that nine of 45 gastric carcinomas with microsatellite instability (MSI) had an AXIN2 frameshift mutation. Pan et al. $(2008)^{27}$ analyzed 70 gastric carcinomas and identified $7.1 \%$ mutation in AXIN gene and concluded that these mutations contributed to gastric carcinogenesis. Mazzoni and Fearon $(2014)^{4}$ reviewed the importance of axin and its variants in gastrointestinal carcinomas and observed that axin protein showed strongly positive expression in neoplastic cells.

CK1 protein can be identified in the cell membrane, nucleus or cytoplasm. Seven members are known in the CK1 family in humans. CK1 epsilon has been related to the phosphorylation of Wnt pathway. There are few studies evaluating the expression of CK1 and its relation with the onset of gastric cancer. As part of the $\beta$-catenin destruction complex, positive protein expression suggests that it may be present in the onset stages of gastric carcinoma ${ }^{4,21}$. In the present study, a strong positive expression of CK1 was observed in the cytoplasm of the neoplastic cells where it normally exerts its function and not in the nucleus.

Ubiquitin is responsible for labeling protein to be degraded from the polyubiquitin chain. Regulating the plasma concentration of $\beta$-catenin as a member of Wnt pathway is performed by destruction complex together with ubiquitin. In the current study, the ubiquitin protein showed strong and identical expressions in the nucleus and cytoplasm. In both nucleus and cytoplasm, protein expression was significantly more intense in moderately or well differentiated tumors and in intestinal type of Lauren's classification ${ }^{23}$.

Arici et al.(2009) ${ }^{3}$ evaluated the expression of cyclin D1 protein in the gastric mucosa and in the neoplastic gastric tissue. Expression of this protein was detected in $72 \%$ of gastric carcinoma cells and $55.8 \%$ of gastric mucosal cells. Such a finding suggests that cyclin D1 expression arises from the initial gastric lesions and tends to remain with tumor progression. We identified positive expression of cyclin D1 only in the nucleus of the neoplastic cells and there was no cytoplasmic expression of this protein. Greater number of tumors of the male patients presented positive expression than tumors of the female patients. Only nuclear expression was expected in view which cyclin D1 is a protein synthesized from stimulation of $\beta$-catenin in the nucleus. This finding suggests that canonical Wnt pathway is activated.

In the present study, c-myc protein expression was positive in cytoplasm in $24.2 \%$ and in nucleus in $42.9 \%$ of the cases. Negative cytoplasmic expression was significantly more frequent in intestinal type of Lauren's classification ${ }^{23}$. Studies have shown that the amplification of the MYC gene in gastric cancer ranges from $38.1 \%$ to $40 \%$. Khaleghian et al. $(2016)^{19}$ evaluated the relationship of expression and amplification of the MYC gene with biodemographic and anatomopathological characteristics of the gastric carcinoma. In situ hybridization was positive in $43 \%$ and positive expression was identified in $14.7 \%$ of the cases. These authors identified the increased expression of MYC in diffuse tumors, unlike Calgano et al. (2013) who identified higher expression of MYC protein in intestinal type of Lauren's classification. In addition, no difference was found in MYC protein expression in relation to tumor stages. Liu et al. (2014) ${ }^{25}$ verified the presence of positive MYC protein expression in $66.3 \%$ of gastric tumors.

There are few studies involving these proteins using the immunohistochemical method and the results obtained are still unclear. However, expressions of the canonical Wnt pathway proteins were high in our samples showing the importance of these proteins. This result taken together creates perspectives for new studies in order to clarify the involvement of Wnt pathway in the onset of gastric carcinoma.

\section{CONCLUSION}

The relation between the expression of canonical pathway proteins and epidemiological and tumor variables suggests their participation in gastric carcinogenesis. On the other hand, the absence of the expression of non-canonical pathway protein expression suggests its non-participation in gastric carcinogenesis

\section{REFERENCES}

1. Altieri DC. Survivin, versatile modulation of cell division and apoptosis in cancer. Oncogene. 2003 Nov;22(53):8581-9.

2. Ara H, Takagishi M, Enomoto A, Asai M, Ushida K, Asai N, et al. Role for Daple in non-canonical Wnt signaling during gastric cancer invasion and metastasis. Cancer Sci. 2016 Feb;107(2):133-9.

3. AriciDS,TuncerE,OzerH,SimekG,KoyuncuA. Expression ofretinoblastoma and cyclin D1 in gastric carcinoma. Neoplasma. 2009;56(1):63-7.

4. Ayed-Guerfali DB, Hassairi B, Khabir A, Sellami-Boudawara T, Gargour A, Mokdad-Gargouri R. Expression of APC, $\beta$-catenin and E-cadherin in Tunisian patients with gastric adenocarcinoma: clinical significance. Tumour Biol. 2014 Mar;35(3):1775-83.

5. Cai $C$, Zhu $X$. The $W n t / \beta$-catenin pathway regulates self-renewal of cancer stem-like cells in human gastric cancer. Mol Med Rep. 2012 May;5(5):1191-6.

6. CalcagnoDQ, Freitas VM, LealMF, deSouza CR, DemachkiS, Montenegro $\mathrm{R}$, et al. MYC, FBXW7 and TP53 copy number variation and expression in gastric cancer. BMC Gastroenterol. 2013 Sep;13:141

7. Cheng $X X$, Wang ZC, Chen $X Y$, Sun Y, Kong QY, Liu J, et al. Correlation of Wnt-2 expression and beta-catenin intracellular accumulation in Chinese gastric cancers: relevance with tumour dissemination. Cancer Lett. 2005 Jun;223(2):339-47.

8. Chiurillo MA. Role of the Wnt/B-catenin pathway in gastric cancer: An in-depth literature review. World J Exp Med. 2015 May;5(2):84-102. 
9. Cho YJ, Kim JH, Yoon J, ChoSJ, Ko YS, ParkJW, et al. Constitutive activation of glycogen synthase kinase-3beta correlates with better prognosis and cyclin-dependent kinase inhibitors in human gastric cancer. BMC Gastroenterol. 2010 Aug; 10:91.

10. DA Silva LC, Forones NM, Ribeiro DA, Ihara SS, Gomes TS, Neto RA et al. Immunoexpression of DIABLO, AIF and cytochrome $C$ in gastric adenocarcinoma assessed by tissue Microarray. Anticancer Res. 2013 Feb;33(2):647-53.

11. Estimativa2016:incidências docâncernoBrasil [databaseonthelnternet] 2016 [cited. Available from: http://www.inca.gov.br/dncc.

12. FerlayJ, Soerjomataram I, ErvikM, DikshitR, EserS, MathersC, etal.Cancer Incidence and Mortality Worldwide: IARC Cancer Base International Agency for Research on Cancer; 2013.

13. Gomes TS, Oshima CT, Segreto HR, Barrazueta LM, Costa HO, Lima FO, et al. The extrinsic apoptotic signaling pathway in gastric adenocarcinomas assessed by tissue microarray. Pathol Res Pract. 2011 Oct;207(10):613-7.

14. Habas R. Canonical Wnt signaling: an unexpected new player. Dev Cell. 2006 Aug;11(2):138-9.

15. Hanaki $H$, Yamamoto $H$, Sakane $H$, Matsumoto $S$, Ohdan $H$, Sato A, et al. An anti-Wnt5a antibody suppresses metastasis of gastric cancer cells in vivo by inhibiting receptor-mediated endocytosis. Mol Cancer Ther. 2012 Feb;11(2):298-307.

16. Ilyas M, StraubJ, Tomlinson IP, BodmerWF.Genetic pathwaysincolorectal and other cancers. Eur J Cancer. 1999 Dec;35(14):1986-2002.

17. Ilyas M.Wntsignalling and themechanistic basis oftumourdevelopment. J Pathol. 2005 Jan;205(2):130-44.

18. Ishimoto T, Oshima H, Oshima M, Kai K, Torii R, Masuko T, et al. CD44+ slow-cycling tumor cell expansion is triggered by cooperative actions of Wnt and prostaglandin E2 in gastric tumorigenesis. Cancer Sci. 2010 Mar; 101(3):673-8.

19. Khaleghian M, Jahanzad I, Shakoori A, Emami Razavi A, Azimi C. Association Between Amplification and Expression of C-MYC Gene and Clinicopathological Characteristics of Stomach Cancer. Iran Red Crescent Med J. 2016 Feb;18(2):e21221.

20. Kim S, Lee J, Hong ME, Do IG, Kang SY, Ha SY, et al. High-throughput sequencing and copy number variation detection using formalin fixed embeddedtissueinmetastaticgastriccancer.PLoSOne.2014;9(11):e111693.

21. Knippschild U, Wolff S, Giamas G, Brockschmidt C, Wittau M, Würl PU et al. The role of the casein kinase 1 (CK1) family in different signaling pathwayslinkedtocancerdevelopment.Onkologie.2005Oct;28(10):508-14

22. Kurayoshi M, Oue N, Yamamoto $H$, Kishida M, Inoue A, Asahara T, et al. Expression of Wnt-5a is correlated with aggressiveness of gastric cancer by stimulating cell migration and invasion. Cancer Res. 2006 Nov;66(21):10439-48.
23. Lauren P. The Two Histological Main Types Of Gastric Carcinoma: Diffuse And So-Called Intestinal-Type Carcinoma. AnAttemptAtA Histo-Clinical Classification. Acta Pathol Microbiol Scand. 1965;64:31-49.

24. Lins RR, Oshima CT, Oliveira LA, Silva MS, Mader AM, Waisberg J. Expression of e-cadherin and wnt pathway proteins betacatenin, apc tcf-4 and survivin in gastric adenocarcinoma: clinical and pathological implication. Arq Bras Cir Dig. 20162016 Nov-Dec;29(4):227-31.

25. LiuX, YuH,CaiH,WangY.Expression ofCD24, p21, p53, and c-mycinalphafetoprotein-producing gastric cancer:Correlation with clinicopathologic characteristics and survival. J Surg Oncol. 2014 Jun;109(8):859-64.

26. Ooi CH, Ivanova T, Wu J, Lee M, Tan IB, Tao J, et al. Oncogenic pathway combinations predict clinical prognosis in gastric cancer. PLoS Genet. 2009 Oct;5(10):e1000676.

27. Pan KF, Liu WG, Zhang L, You WC, Lu YY. Mutations in components of the Wnt signaling pathway in gastric cancer. World J Gastroenterol. 2008 Mar:14(10):1570-4.

28. Pereira MA, Ramos MFKP, Dias AR, Yagi OK, Faraj SF, Zilberstein B, et al. Detection of occult lymph node tumor cells in node-negative gastric cancer patients. Arq Bras Cir Dig. 20172017 Jan-Mar;30(1):30-4.

29. Shojima K, Sato A, Hanaki H, Tsujimoto I, Nakamura M, Hattori K, et al. Wnt5a promotes cancer cell invasion and proliferation by receptormediated endocytosis-dependent and -independent mechanisms, respectively. Sci Rep. 2015 Jan; 5:8042.

30. van der Woude CJ, Kleibeuker JH, Tiebosch AT, Homan M, Beuving A, Jansen $\mathrm{PL}$, et al. Diffuse and intestinal type gastric carcinomas differ in their expression of apoptosis related proteins. J Clin Pathol. 2003 Sep;56(9):699-702.

31. Vider BZ, Zimber A, Chastre E, Prevot S, Gespach C, Estlein D, et al. Evidence for the involvement of the Wnt 2 gene in human colorectal cancer. Oncogene. 1996 Jan;12(1):153-8.

32. WhiteBD,ChienAJ,DawsonDW.DysregulationofWnt/ $\beta$-cateninsignaling in gastrointestinal cancers. Gastroenterology. 2012 Feb;142(2):219-32.

33. Yamamoto $H$, Kitadai Y, Oue N, Ohdan H, Yasui W, Kikuchi A. Laminin gamma2 mediates Wnt5a-induced invasion of gastric cancer cells. Gastroenterology. 2009 Jul;137(1):242-52, 52.e1-6.

34. Zhang Y, Du J, Zheng J, Liu J, Xu R, Shen T, et al. EGF-reduced Wnt5a transcription induces epithelial-mesenchymal transition via Arf6-ERK signaling in gastric cancer cells. Oncotarget. 2015 Mar;6(9):7244-61.

35. Zheng H, TakahashiH,MuraiY, CuiZ, NomotoK,MiwaS, etal.Pathobiological characteristics of intestinal and diffuse-type gastric carcinoma in Japan: an immunostaining study on the tissue microarray. J Clin Pathol. 2007 Mar;60(3):273-7. 